\title{
Evaluation of Mechanical Properties of Sealing Mortar with Partial Replacement of Portland Cement by Stone Crusher Waste
}

\author{
Matheus Henrique Dossena ${ }^{a}$, Diogo Bevilaqua ${ }^{a}$, Luciano Luiz Silva ${ }^{a}$, Márcio Antônio Fiori ${ }^{a, b *}$ *
}

Eduardo Roberto Batiston ${ }^{a}$, Josiane Maria Muneron de Mello ${ }^{a, b}$

\begin{abstract}
aPrograma de Pós-Graduação em Tecnologia e Gestão da Inovação - PPGTI, Área de Ciências Exatas e Ambientais, Universidade Comunitária da Região de Chapecó - Unochapecó, Chapecó, SC, Brasil ${ }^{b}$ Programa de Pós-Graduação em Ciências Ambientais - PPGCA, Area de Ciências Exatas e Ambientais, Universidade Comunitária da Região de Chapecó - Unochapecó, Chapecó, SC, Brasil
\end{abstract}

Received: December 17, 2018; Revised: June 6, 2019; Accepted: July 15, 2019

\begin{abstract}
Civil construction is one segment responsible for major environmental and social impacts. Among its raw materials, Portland cement, which is produced by the burning and subsequent grinding of a composition of clays and limestones. This manufacturing process causes great environmental damage, both by the exploitation of deposits and by the process of clinkering (burning of raw materials), which emits a significant amount of $\mathrm{CO}_{2}$ in the atmosphere. Therefore, there is a need for research on materials that reduce these impacts on the environment and that can be used by civil construction to the partial replacement of cement. Thus, this research had as objective to produce settlement mortar through the partial replacement of the Portland cement by filler powder, in different proportions and to study its mechanical properties. The results show that the partial replacement of the cement by the residue has acceptable behavior in the mortar.
\end{abstract}

Keywords: Portland cement, basaltic filler, reuse of waste.

\section{Introduction}

The cement industry has a high potential for contamination, generating pollution at almost all stages of the cement production process, ranging from the extraction, grinding and homogenization of raw materials, to clinker, cooling and grinding of the clinker, making the cement factory one of the major sources of carbon dioxide $\left(\mathrm{CO}_{2}\right)$ emissions, in addition to the high energy consumption demanded, especially in clinkerization ${ }^{1-5}$. The cement industry consumes approximately $12-15 \%$ of the world's industrial energy and it's responsible for at least $5 \%$ of the world's $\mathrm{CO} 2$ emissions ${ }^{6,7}$.

Today gas emissions are great environmental concern in the cement industry, that to produce one tonne of clinker, approximately one tonne of $\mathrm{CO}_{2}$ is released into the environment, where approximately $579 \mathrm{~kg}$ of $\mathrm{CO}_{2}$ is emitted to one tonne of clinker, plus approximately $390 \mathrm{~kg}$ of $\mathrm{CO}_{2}$ as a function of the use of fossil fuels during production $^{8}$.

On the other hand, the construction industry has been of extreme importance for the development of the modern economy and with it, the demand for aggregates to supply the demand in the last decade had a big growth ${ }^{9,10}$.

Mortar, being one of the main materials used by the construction industry, presents high potential to absorb alternative materials from industrial tailings and wastes from the construction itself. The adoption of practices for

*e-mail: marciofiori@gmail.com a reuse and recycling of different type of residues to avoid environmental pollution is mostly desirable as it contributes to sustainable development ${ }^{11}$. The civil construction industry appears as the best solution to overcome this environmental issue and the incorporation of residues in mortars can result not only technical advantages but also cost reduction of the fabricated products since the residues are considered waste materials for the industry ${ }^{12}$.

Thus, several researchers studied technical feasibility for the incorporation of different residues in the production of mortars, aiming at the partial replacement of the cement, which is the most important agglomerant in the production of the mortar. Among them, they evaluated the use of marble residues $^{13,11}$, eggshell powder ${ }^{8}$, waste paper and cellulose, as well as construction and demolition industries for application in cement-based materials ${ }^{14}$, biomass residue from a pulp and paper mill ${ }^{15}$, heavy ash obtained from the combustion of mineral coal ${ }^{16}$, biomass ash ${ }^{17}$ and sewage sludge ${ }^{18}$. These articles aim to contribute to the sustainable development by making greater use of industrial residues in the civil construction as mortars ${ }^{12}$ and concrete ${ }^{19}$.

An industrial residue that deserves attention is the rock powder, from rock crushing, also known as filler or gravel powder. During the exploration of the quarry, more specifically in the extraction, transport and crushing of rocks, large amounts of powder is generated. The handling and incorrect disposal of this residue can generate serious environmental problems, and its accumulation and dispersion 
directly contaminate the soil and surface waters, and may even deteriorate groundwater through the production of drainage $\mathrm{e}^{10}$. Due to the fact that there is no commercialization and the commercial value involved is very low, this residue is often stored in the quarries, causing impacts such as air pollution due to the presence of particulate matter, pollution of water bodies caused by drainage of fine materials and also visual pollution of the site $\mathrm{e}^{20,9,21}$.

Researchers have been developing methods to properly dispose of these wastes generated during the crushing process, using them as feedstock to produce clinker or even as a mineral addition in Portland cements ${ }^{22,23}$, but the use of basaltic filler replacing partially the cement, in the production of mortar, hasn't been evaluated yet. In view of this context, the objective of this study was to obtain settlement mortar through the partial replacement of the Portland cement by residue generated from the crushing process of basaltic rock, basaltic filler. The mortar obtained was characterized, through mechanical tests, with the intention to evaluate if it meets all the technical requirements of use foreseen in the standard norms of the civil construction.

\section{Materials and Methods}

For this study, the following materials were used: sand, classified as per ABNT (Brazilian Association of Technical Standards $) \mathrm{n}^{\circ} 5 / 8$ " sieve $(1.2 \mathrm{~mm})$ and bulk density of $2.64 \mathrm{~g} \mathrm{~cm}^{-3}$; Portland cement, model CP II Z-32, of the Votoran, specific mass of $2.96 \mathrm{~g} \mathrm{~cm}^{-3}$; filer residues from the stone crusher from Cordilheira Alta, state of Santa Catarina, Brazil.

Initially the filer residues were physically characterized by specific mass for NBR NM $52^{24}$, particle size in the laser diffraction analyser (Microtrac, S3500). It was also chemically characterized by fluorescence X-rays analysis (XRF) in a Panalytical spectrometer, Axios Max model. For the mineralogical characterization, X-ray diffraction (XRD) was performed in a Bruker diffractometer (Bruker, D8 model), with theta - theta goniometer. The $\mathrm{x}$-ray radiation employed was $\mathrm{K} \alpha$ - Copper generated under the conditions of $40 \mathrm{kV}$ and $40 \mathrm{~mA}$. The speed and scan interval of the goniometer used were $1 \mathrm{~g}$ of powder at $1 \mathrm{~s}$ to $0.02^{\circ}$ of the goniometer from $2^{\circ}$ to $72^{\circ} 2$ theta, respectively. TGA analysis was also performed. The equipment used was a TGA Netzsch, model STA $409 \mathrm{EP}$, and the tests were carried out with a heating rate of $10{ }^{\circ} \mathrm{C} \mathrm{min}^{-1}$, starting at room temperature and ending at $910{ }^{\circ} \mathrm{C}$. The cement was also characterized by XRF and XRD.

The mortars were produced according to NBR $13276^{25}$. The dosage of the mixtures was established, in the proportions of 1: 3: 0.56 (wt $\%$ ) of cement, sand and water, respectively. Before use, the sand was oven dried (QUIMIS, Q314M) at 105 ${ }^{\circ} \mathrm{C}$ for $24 \mathrm{~h}$. The residues used were those how have passed through the sieve at $300 \mu \mathrm{m}$ and after were then oven dried for $24 \mathrm{~h}$ at $105^{\circ} \mathrm{C}$. The residues replace the cement in five mixes in different proportions, being 5\%, 10\%, 15\%, 20\% and $30 \%$ (wt $\%$ ), maintaining the relationship between water and cement $(\mathrm{w} / \mathrm{c})$ adopted for the reference mix. The assays were completed in triplicate. All compositions were compared to the reference (control) sample without residues. Table 1 presents the composition of the investigated residues-cement mixtures.

For each mix, 36 specimens were produced, being that 18 were molded in the cylindrical dimensions of $5 \times 10 \mathrm{~cm}^{3}$, according to NBR $7215^{26}$ and 18 were molded in the prismatic dimensions of $4 \times 4 \times 16 \mathrm{~cm}^{3}$, according to NBR $13279^{27}$. These 18 blocks 9 were molded to curing process over a period of 7 days and 9 to a period of 28 days. The curing process was performed in controlled temperature of $25^{\circ} \mathrm{C}$.

The consistency index and water absorption determination in mortars were determined according to Brazilian Standard NBR $13276^{25}$ and NBR $13277^{28}$, respectively.

It was determined, in the hardened state, the flexural tensile strength and the compressive strength through the Brazilian Standard NBR $13279^{27}$. The mechanical tests were used a universal mechanical test press (Shimadzu, AG-X Plus) with capacity to $100 \mathrm{kN}$ and speed of $50 \pm 10 \mathrm{~N} \mathrm{~s}^{-1}$. According to the same standard, the axial compressive strength was obtained, where the same press was used, at a speed of $500 \pm 50 \mathrm{~N} \mathrm{~s}^{-1}$. The test to tensile strength diametrical compression were done according to NBR $7222^{29}$. It was used the same press, at a speed of $0.05 \pm 0.02 \mathrm{MPa} \mathrm{s}^{-1}$. The mechanical tests were statistically analyzed using Statistica ${ }^{\circledR} 12.0$ (StatSoft ${ }^{\circledR}$, USA), using Tukey's test with $5 \%$ probability $(\mathrm{p} \leq 0.05)$ using analysis of variance (ANOVA).

Table 1. Compositions (w\%) of the filer residues cement mixtures to production of mortars.

\begin{tabular}{lccccc}
\hline \multirow{2}{*}{ Mix } & residues & sand & cement & residue & water \\
\hline Reference/Control & $0 \%$ & 30.690 & 10.230 & 0.000 & 5.852 \\
A & $5 \%$ & 30.690 & 9.718 & 0.512 & 5.852 \\
B & $10 \%$ & 30.690 & 9.207 & 1.023 & 5.852 \\
C & $15 \%$ & 30.690 & 8.695 & 1.535 & 5.852 \\
D & $20 \%$ & 30.690 & 8.184 & 2.046 & 5.852 \\
E & $30 \%$ & 30.690 & 7.161 & 3.069 & 5.852 \\
\hline
\end{tabular}


Tests to available the pozolanicity of the basaltic filler were made according NBR $5751^{30}$ (2015). The technical standard suggests the production and tests of the mortar samples with $\mathrm{Ca}(\mathrm{OH})_{2}$ and the cure at $55^{\circ} \mathrm{C}$ by 7 days. The mortar samples were submitted to compression tests using a universal mechanical test press (Shimadzu, AG-X Plus) with capacity to $100 \mathrm{kN}$ and speed of $50 \pm 10 \mathrm{~N} \mathrm{~s}^{-1}$. According to the same standard, the axial compressive strength was obtained, where the same press was used, at a speed of 500 $\pm 50 \mathrm{~N} \mathrm{~s}^{-1}$. The criteria considered to define a pozzolanic sample were the compression resistance values higher than $6 \mathrm{MPa}$, according NBR $12653^{31}$ (2015).

\section{Results and Discussion}

\subsection{Characterization of cement and waste}

Figure 1 shows the granulometric distribution of the filer residues and cement used. It is possible to observe that the amount of cement used for the mortar production presented to be a very fine material, where only $5.97 \%$ of material was retained in the 200 mesh sieve (aperture $0.074 \mathrm{~mm}$ ), different from the residue, which presented larger particles, totaling $69.54 \%$ of the material retained in the same sieve. Only $10 \%$ of the cement particles had a diameter less than $3.27 \mu \mathrm{m}$, while the residue had a diameter of less than 31.11 $\mu \mathrm{m}$ in $10 \%$ of the particles, thus showing the granulometric difference between the materials. The density of the filer residue was calculated $2.86 \pm 0.0122 \mathrm{~g} \mathrm{~cm}^{-3}$.

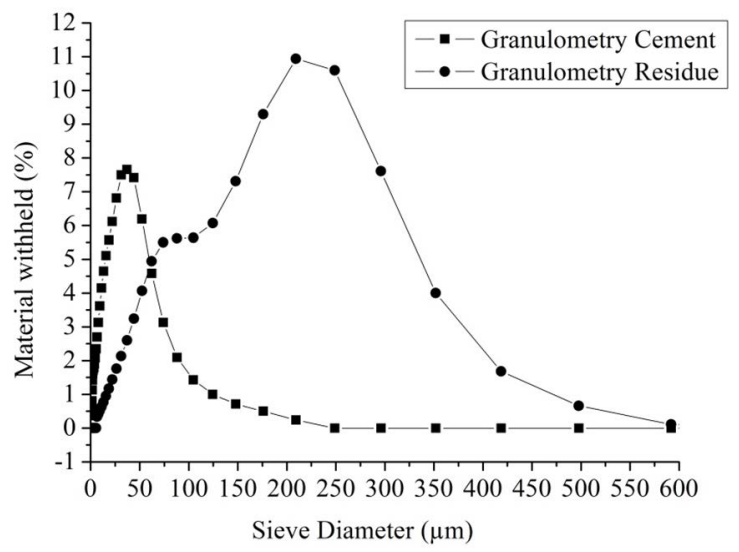

Figure 1. Filer residue and cement granulometric curve.

The optimization of the compactness in the cement paste is carried out using a material of higher particle size and one of smaller particle size in relation to the cement, so the filer used in this work can provide a better packaging of the materials and consequently a gain in the mechanical resistance, because the smaller particles tend to fit into the voids between the average particles, which in turn occupy the voids of the larger particles ${ }^{32}$.
Table 2 presents the XRF chemical analysis of the filer (crusher residue) and cement. It is found that the crusher residue is composed predominantly of $\mathrm{SiO}_{2}, \mathrm{Al}_{2} \mathrm{O}_{3}$ and $\mathrm{Fe}_{2} \mathrm{O}_{3}$, totaling approximately $78.5 \%$ by mass. According to NBR $12653^{31}$, it can be said that this residue possesses a possible pozzolanic characteristic, being possible to fit it to the classification for pozzolanic materials. The residue sample shows chemical compatibility with the main raw materials used to produce cement clinker, which is alite and belite, that is, this similarity is due to the main oxides present in the residue $\left(\mathrm{SiO}_{2}, \mathrm{Fe}_{2} \mathrm{O}_{3}\right.$ and $\left.\mathrm{Al}_{2} \mathrm{O}_{3}\right)$.

Table 2. Chemical composition (mass percent) by XRF of the filer and cement.

\begin{tabular}{|c|c|c|}
\hline $\begin{array}{l}\text { Chemical composition } \\
\text { (oxides) }\end{array}$ & Cement $(\%)$ & Residue (\%) \\
\hline $\mathrm{Al}_{2} \mathrm{O}_{3}$ & 5.75 & 13.50 \\
\hline $\mathrm{CaO}$ & 52.38 & 8.09 \\
\hline $\mathrm{Fe}_{2} \mathrm{O}_{3}$ & 3.10 & 13.04 \\
\hline $\mathrm{K}_{2} \mathrm{O}$ & 1.34 & 1.53 \\
\hline $\mathrm{MgO}$ & 5.60 & 4.01 \\
\hline $\mathrm{MnO}$ & 0.10 & 0.18 \\
\hline $\mathrm{Na}_{2} \mathrm{O}$ & 0.30 & 3.18 \\
\hline $\mathrm{P}_{2} \mathrm{O}_{5}$ & 0.13 & 0.47 \\
\hline $\mathrm{SiO}_{2}$ & 23.35 & 51.91 \\
\hline $\mathrm{TiO}_{2}$ & 0.32 & 3.00 \\
\hline $\mathrm{B}_{2} \mathrm{O}_{3}$ & - & - \\
\hline $\mathrm{Li}_{2} \mathrm{O}$ & - & - \\
\hline $\mathrm{BaO}$ & - & $<0.1$ \\
\hline $\mathrm{Co}_{2} \mathrm{O}_{3}$ & - & $<0.1$ \\
\hline $\mathrm{Cr}_{2} \mathrm{O}_{3}$ & - & $<0.1$ \\
\hline $\mathrm{PbO}$ & - & $<0.1$ \\
\hline $\mathrm{SrO}$ & 0.28 & $<0.1$ \\
\hline $\mathrm{ZnO}$ & $<0.1$ & $<0.1$ \\
\hline $\mathrm{ZrO}_{2}+\mathrm{HfO}_{2}$ & $<0.1$ & $<0.1$ \\
\hline Loss on ignition & 5.44 & 0.93 \\
\hline
\end{tabular}

According to the chemical composition of the cement, presented in Table 2, it is possible to classify it, according to NBR $16697^{33}$, as CP II-Z cement, because it meets the conditions established by the NBR in relation to the amount of magnesium oxide (MgO), less than $6.5 \%$ and less than $4.0 \%$ of sulfur trioxide $\left(\mathrm{SO}_{3}\right)$, which for the cement used was not registered. The presence of calcium oxide $(\mathrm{CaO})$ and magnesium oxide $(\mathrm{MgO})$ are characteristic compounds of carbonate rocks ${ }^{34}$. For application in cements, the magnesium oxide content is generally limited to $5 \%$, because amounts of this component in excess can cause slow reactions with water, which may lead to the destructive expansion of hardened concrete $^{35}$. For the case of the residue, the amount found was less than 5\%, which allows its application in cements. 
The Figure 2 shows the X-ray diffractogram of the cement and Figure 3 shows the X-ray diffractogram of filer. It is possible to note the typical peaks of quartz, expressed by the number " 1 ", alite, indicated by the number " 2 " and belite, number " 3 ", which are constituents of the Portland cement $^{36,37}$. This result confirms the data presented by the chemical analysis of the material in Table 2.

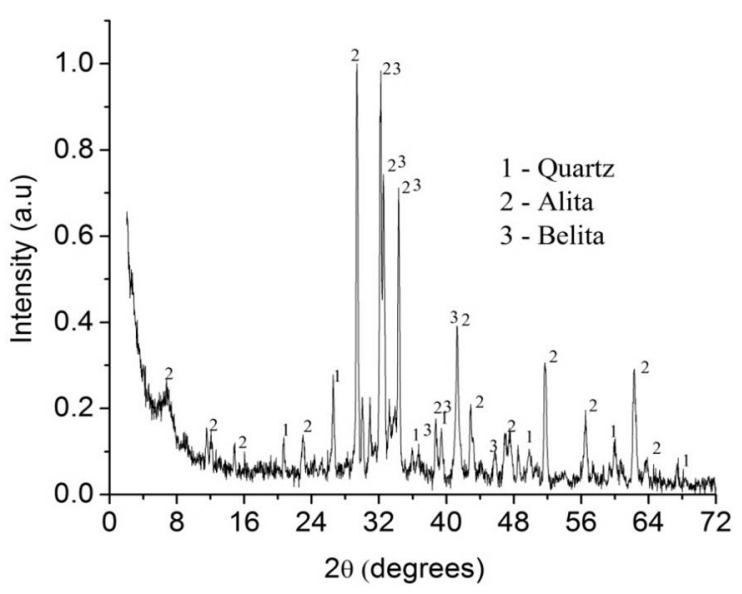

Figure 2. X-ray diffractogram of cement.

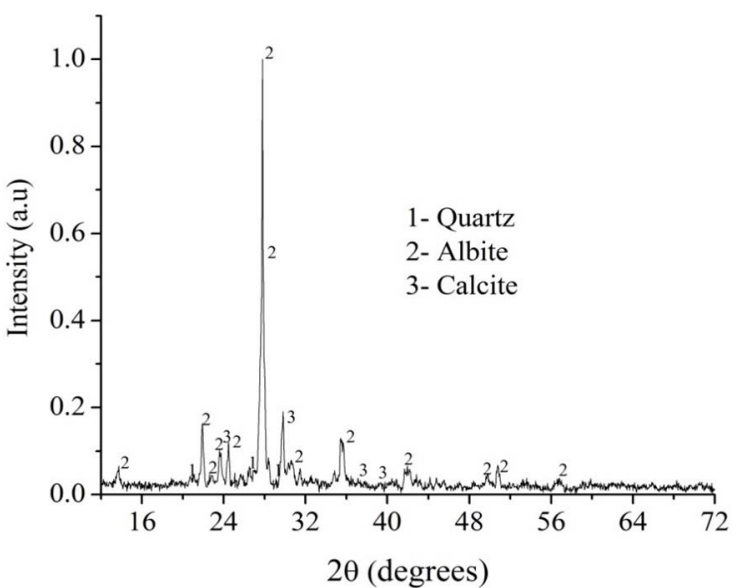

Figure 3. Diffractogram of the crusher residue used in the production of mortars.

Table 3 presents a mineralogical composition obtained through the XRD analysis of the cement. The cement presents $83.60 \%$ alite in its composition. This result was expected, because the alite must be the main constituent of the clinker after the processing, because it is its hydration reaction that confers the mechanical resistance to the cured cement, generating hydration products with high initial mechanical strength, hardening, and as it is more reactive than the belita, participates in the initial phases of hydration, being responsible for a great amount of the released heat. While the belite forms cements known as low energy, however with a slower increase of mechanical resistance ${ }^{3,38-40}$. The presence of quartz in the composition was expected, due to the presence of $\mathrm{SiO}_{2}$ of the kaolite clay in clinker production. The quartz when in high contents (above 10\% in relation to the cement mass) can reduce the quality of cement, either by its inert character or by the high hardness ${ }^{41}$.

Table 3. Mineralogical composition obtained through the XRD analysis of cement.

\begin{tabular}{lc}
\hline Mineralogical Phase & Percentage in the sample (\%) \\
\hline Quartz & 5.47 \\
Alite & 83.60 \\
Belite & 10.93 \\
\hline
\end{tabular}

Through Figure 3, which presents the diffractogram for the residue (filler), it is possible to identify the crystalline phases corresponding to the quartz (number " 1 ") albite $\left(\mathrm{NaAlSi}_{3} \mathrm{O}_{8}\right)$ (number " 2 ") and calcite (number " 3 "). The Table 4 presents the mineralogical composition obtained through the filler XRD analysis.

Table 4. Mineralogical composition obtained by the XRD analysis of the crusher residue.

\begin{tabular}{lc}
\hline Mineralogical Phase & Percentage in the sample (\%) \\
\hline Quartz & 1.58 \\
Albite & 87.36 \\
Calcite & 11.07 \\
\hline
\end{tabular}

Through Table 4, it is verified that the major compound present in the filer was the albite, with $87.36 \%$, followed by calcite $(11.07 \%)$ and quartz $(1.58 \%)$. The albite is a common mineral in the feldspar, typical of alkaline and acidic magmatic rocks belonging to the group of plagioclases, that the more calcics, end up providing losses of calcium and aluminum in its composition, thus generating the albite. Its presence in feldspar is explained because it is the last mineral to crystallize in molten $\operatorname{rock}^{42,43}$. The albite is presented as a mineral that is widely used by the industry in the production of refractory artifacts due to its high resistance to heat ${ }^{44}$. In relation to calcite and quartz, they are very common minerals in the Earth's crust, because they form part of the mineralogical composition of igneous and metamorphic rocks, corresponding approximately $95 \%$ of the terrestrial layer ${ }^{45}$.

By analyzing the results of the XRD, it can be said that none of the minerals that constitute the crusher residue could hinder the use of this material as a component of the mortar.

The results of the thermogravimetric analysis (TG) and its respective derivative (DTG) performed for the crusher residue are shown in Figure 4. The thermogram indicates the loss of $1 \%$ mass with the heat treatment up to $100{ }^{\circ} \mathrm{C}$, the remaining mass constant until temperature of $750{ }^{\circ} \mathrm{C}$, where there is a small loss (less than $1 \%$ ). The first mass 


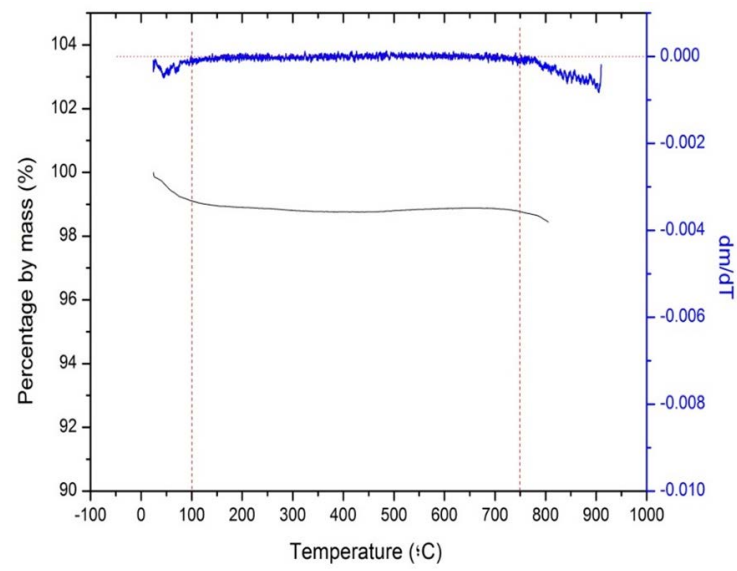

Figure 4. Thermogram of crusher residue and Differential TGA thermogram for crusher residue.

loss is possibly due to the volatilization of water molecules present on the surface of the material.

From the DTG thermogram it is possible to identify a constant behavior in the mass of the material, that is, without loss of mass until the temperature of $750{ }^{\circ} \mathrm{C}$, where it is observed a loss of mass of $2.4 \%$, due to a possible thermal decomposition of the calcite, promoted by the gas release carbon dioxide $\left(\mathrm{CO}_{2}\right)$. The thermal decomposition of the calcite $\left(\mathrm{CaCO}_{3}\right)$ occurs from $700^{\circ} \mathrm{C}$, with phase transformation at $850{ }^{\circ} \mathrm{C}$, resulting in the formation of lime $(\mathrm{CaO})$ and $\mathrm{CO}_{2}$ release and the relationship between the calcite mass loss $\left(\mathrm{CaCO}_{3}\right)$ and the decomposition of the organic matter occurs between the temperatures of $350{ }^{\circ} \mathrm{C}$ and $800^{\circ} \mathrm{C}^{14,45,46}$.

By the TGA analysis, a percentage of $96.7 \%$ of residue was obtained up to $900^{\circ} \mathrm{C}$, therefore, the residue presented a thermal characteristic behavior with very low mass loss $(2.4 \%)$. This result confirms too, the loss on ignition obtained by the chemical analysis, indicating a low number of contaminants.

\subsection{Characterization of the mortar in the fresh state}

The results of the consistency (workability) of the six mortars obtained are shown in Figure 5 and the water retention results are expressed in Figure 6. Which one sample is the reference and the others are the in different proportions of residue, $5 \%, 10 \%, 15 \%, 20 \%$ and $30 \%$, replacing the cement. The results are expressed as mean values of the tests, and the averages followed by the same letter in the column do not differ from each other by the Tukey test at $5 \%$ probability.

From Figure 5, it can be observed that for sample A, with a $5 \%$ substitution of the cement by crusher residue, the consistency increased by $12.41 \%$ in relation to the reference sample, showing that there is statistically significant difference when compared to the sample reference. However, this behavior is not observed for samples $\mathrm{B}, \mathrm{C}$ and $\mathrm{D}$, which

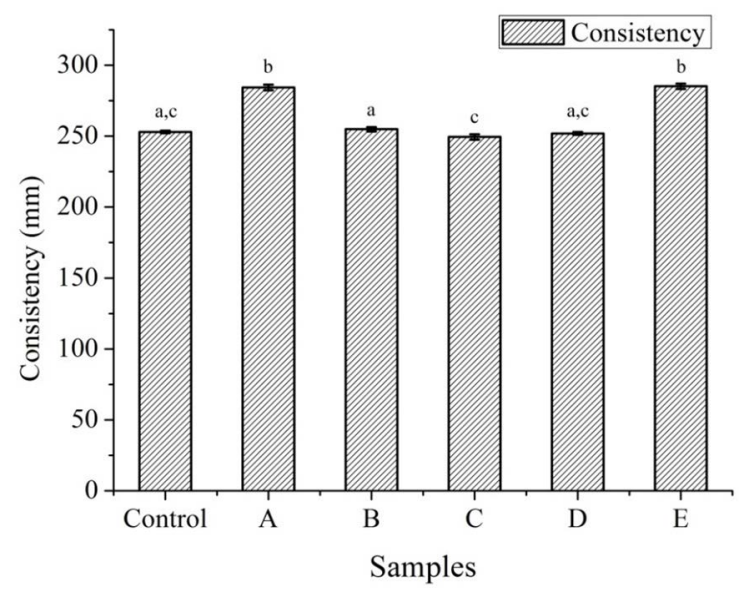

Figure 5. Results of the consistency of the reference mortar and the mortar with $5 \%, 10 \%, 15 \%, 20 \%$ and $30 \%$ of residual in partial replacement of the cement.

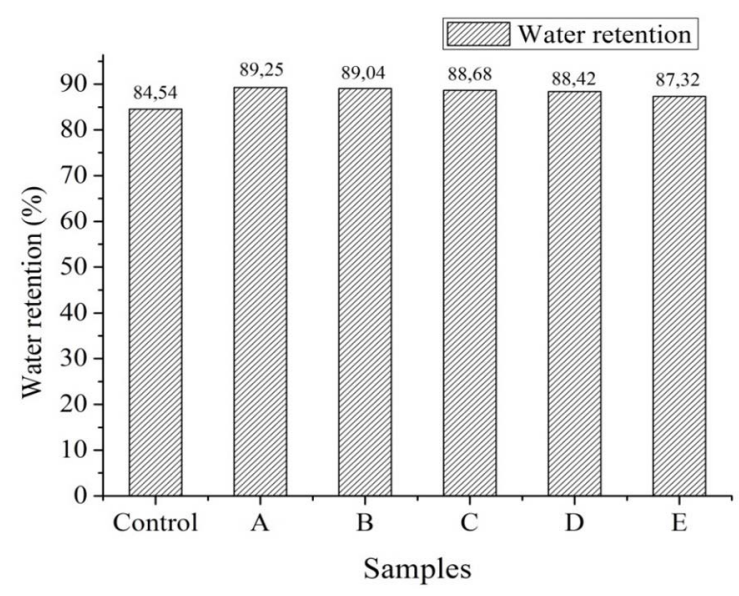

Figure 6. Results of the water retention test on the reference mortar and on the mortar with $5 \%, 10 \%, 15 \%, 20 \%$ and $30 \%$ of residue in partial replacement of the cement.

did not show a significant difference when compared to the reference sample. According to NBR $13276^{25}$, for a mortar presenting good workability it must have a standard consistency of $255 \pm 10 \mathrm{~mm}$, so the samples with $10 \%, 15 \%$ and $20 \%$ of residue comply with that standard. Therefore, it can be said that samples B, C and D show good workability, that is, they adhere well to the trowel, slide smoothly, and easily deform under loads. While the samples A and $\mathrm{E}$ were outside the range of values stipulated by the standard, possibly because the particles of the residue are immersed inside the binder, without internal cohesion and with tendency to deposit by segregation, in this way, the mortar spreads without allowing the proper execution of the work.

Figure 6 shows that the addition of the residue in the mortar and, consequently, the reduction of the cement, generated a higher percentage of water retention, with a maximum value of $5.57 \%$ in relation to the reference sample. The values presented in Figure 6 show that all mortars with 
residuals have a normal water retention, according to NBR $13277^{28}$, which standardizes as normal 80 to $90 \%$ retention and as high above $90 \%$. The mortar must retain the settling water which serves both to lubricate the dry materials and to ensure cement hydration ${ }^{47}$. The retention of water influences some characteristics of the mortar coating, not only in the fresh state, but also in the hardened state, as the evolution of the hardened ${ }^{48}$.

\subsection{Characterization of the mortar in the hardened state}

The obtained mortars were characterized in the hardened state as the tensile strength in flexion, resistance to compression in the prism and the tensile strength in diametrical compression, with a curing time of 7 and 28 days. The results presented are the average of each test with its respective standard deviation and the averages followed by the same lowercase letter in the 7-day column and the averages followed by the same capital letter in the 28-day column do not differ from each other by the Tukey test at $5 \%$ probability.

Figure 7 presents the results of the flexural tensile strength test of the mortar samples obtained with different proportions of the residue and the reference mortar in the hardened state at 7 and 28 days.

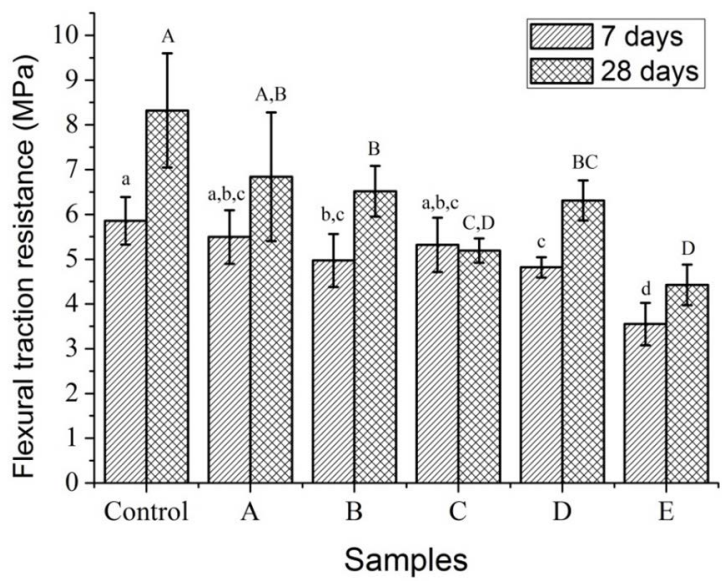

Figure 7. Results of tensile strength in flexion of mortar samples obtained with different proportions of the residue, in the hardened state at 7 and 28 days.

It can be seen from Figure 7 that for the 7-day samples, a tendency was observed in the reduction of tensile strength in flexion as the cement was replaced by the residue. This behavior was expected because the introduced residue behaves as an inert material, and the reactive material, in this case the cement, is withdrawn in the same proportion. This perception is visualized for the $\mathrm{D}$ and $\mathrm{E}$ mixes, where they presented a significant reduction in tensile strength in flexion, of 17.75 and $36.52 \%$, respectively, when compared with the control sample. However, samples A, B and C (5\%, 10\% and 15\%) did not differ significantly from the control sample. Mix $\mathrm{C}$, with $15 \%$ of residue, presented the best performance among the mortars with residue, presenting a decrease of resistance of $9.21 \%$ in relation to the reference sample.

For mortars aged 28 days, Figure 7, it was also observed that there was a decrease in the tensile strength in the flexion when comparing the mix reference to the other mortars. Sample A was the one that presented better performance in relation to mixes with substitution, presenting no statistically significant difference when compared to the reference mix. The mixes $\mathrm{C}$ and $\mathrm{E}$ showed the greatest decrease in tensile strength, being 37.62 and $46.75 \%$, respectively. When comparing tensile strength in flexion at the age of 7 and 28 days, it is verified that for higher age, there is an increase in resistance, since it is believed that there was not enough time for hydration in the mortar mass.

The variation of the compressive strength of the mortars containing the residue and the reference mortar, after 7 and 28 days of cure, is shown in Figure 8. For mortars at the age of 7 days, a reduction in compressive strength was observed as the percentage of residue increased, except for the mix $\mathrm{C}$ which presented a $13.91 \%$ increase in resistance when compared to the reference mix. In the mix E was observed the least resistance, being $40.99 \%$ smaller than the reference mix. However, for mortars with 28 days of age, there was a small decrease in resistance to mix A, B and C, when compared to the reference mix, with no statistically significant difference. When comparing the reference sample with the D and $\mathrm{E}$ mixes, these showed a significant difference. The mix $\mathrm{C}$, replacing $15 \%$ of the residue with cement, was the one that presented better performance with the replacement of cement, having only a decrease of $6.27 \%$ in the resistance.

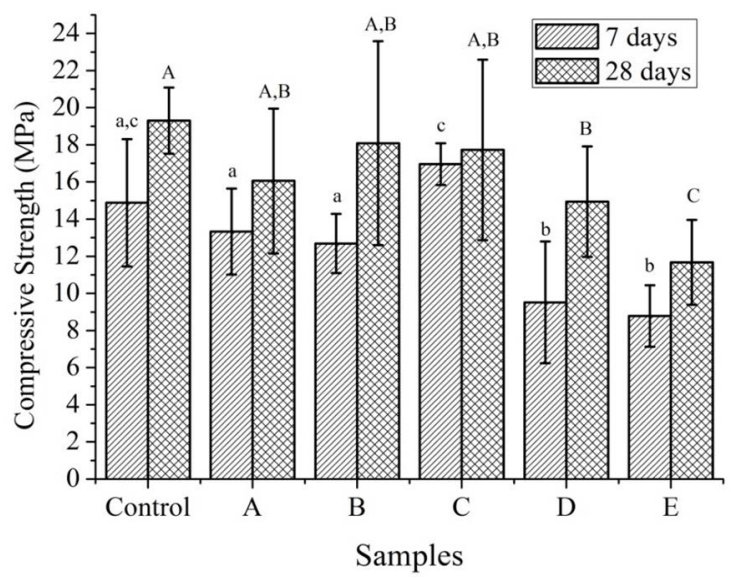

Figure 8. Results of the compressive strength of mortars obtained with different proportions of the residue, in the hardened state at 7 and 28 days.

The fact that the compressive strength did not suffer significant interference in samples A, B and C is possibly due to the microfiller effect of the powder, where the smaller particles of the dust fit into the voids of the particles of the aggregate and binder, filling the pores of the mortar and 
making them discontinuous. For the other mixes, D and $\mathrm{E}$, the decrease can be the removal of a larger quantity of cement and the introduction of the inert material, as already mentioned. As with tensile strength in flexion, the increase in compressive strength may have occurred until the closure of the sizing package and decrease in the sequence, with increase in the contents of substitutions and reduction in the quantity of cement, results also observed by Canova ${ }^{49}$. The decrease in resistance, in this case, can be explained by De Larrard $^{50}$, which states that after full completion is reached, any fine grain that is added to the mixture can produce the removal effect of the larger grains, that is, the fine particles are added and do not fit perfectly between the apertures of the smaller particles damaging the densification. Thus, an increase in pore volume and a decrease in packing density occurs, which may adversely affect the strength of the mortar.

The results obtained of the tensile strength in the diametrical compression for the mortars obtained using the residue and for the reference mortar are presented in Figure 9, for 7 and 28 days of cure.

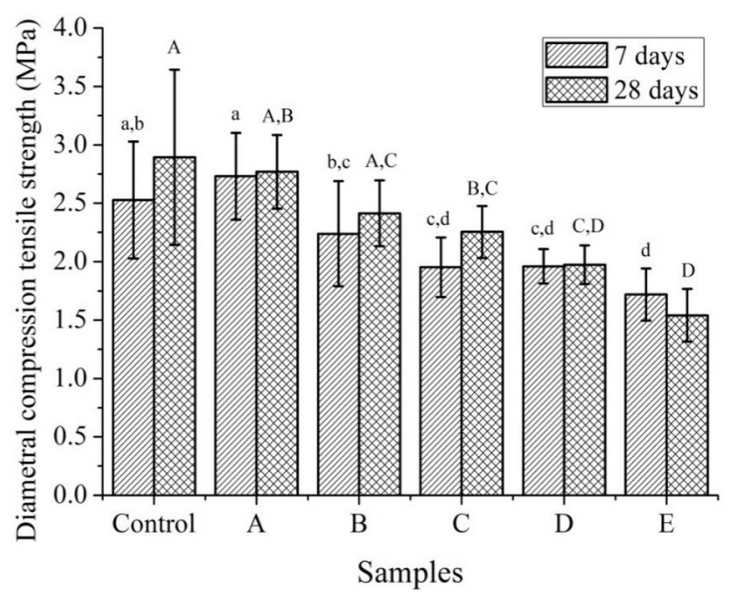

Figure 9. Result of tensile strength with diametrical compression in mortars, in the hardened state of 7 and 28 days.

It can be verified for mortars A, B and C, aged 7 days, there was an increase in mix A, B and C, and a statistically significant reduction in the $\mathrm{D}$ and $\mathrm{E}$ mixes compared to the reference mix. Mix A presented a 1.10\% increase in tensile strength when compared to the reference mix. It is observed that the mix E presented a reduction of $36.30 \%$ in tensile strength with diametral compression, when compared to the reference mix. It has been found that the tendency is to reduce the tensile strength of the mortar as the proportion of residue increases. However, for the proportions of $5 \%$ and $10 \%$ of residue in substitution to the cement, there is no significant difference in the tensile strength when compared to the resistance of the control mix. For sample E, with $30 \%$ residual and $30 \%$ less cement, the decrease in compressive strength was $46.71 \%$ in relation to the reference mix, proving to be statistically significant the difference between these mixes.

\subsection{Tests for the pozolanicity of the mortar}

The mortar samples were submitted to pozolanicity tests according NBR $5751^{30}$ (2015) with simple compression tests, Table 5. The results shown that not is possible to define the basaltic fillers as a pozzolanic material because the values of the medium maximum values of the compression resistance of the mortar samples containing the basaltic filler is 0.28 $\mathrm{MPa}$, lower than 6.00 MPa, defined by the NBR $12653^{31}$ (2015). So, the effect of the basaltic filler in the mortar is only to substitute the cement and to compensate the mechanical resistances.

Table 5. Medium maximum values of the compression resistance of the mortar samples containing the basaltic filler.

\begin{tabular}{lc}
\hline Sample & $\begin{array}{c}\text { Rupture stress } \\
(\mathrm{MPa})\end{array}$ \\
\hline 1 & 0.27 \\
2 & 0.30 \\
Average & 0.28 \\
\hline
\end{tabular}

\section{Conclusion}

From the laser granulometric analysis of the residue it was possible to observe that its particles were larger than the particles of the cement, providing a better sizing between the aggregate/binder. Through the FRX in the residue, it was possible to verify a percentage of $78.45 \% \mathrm{SiO}_{2}, \mathrm{Al}_{2} \mathrm{O}_{3}$ and $\mathrm{Fe}_{2} \mathrm{O}_{3}$, which according to NBR $12563^{23}$, the material has pozzolanic characteristics.

It is possible to observe that the higher the substitution of cement by residue, the lower its resistance, this effect may be related to the substitution of the reactive material by a material with low reactivity, and may also be related to the a/c factor that was not altered as the cement was replaced by the residue, implying an increase in porosity and consequently the decrease of the resistance.

It is possible to highlight the mortar with partial replacement of $10 \%$ of Portland cement by crusher residue, where it presented behavior close to the reference mix. The good results may be related to the ideal particle size closure, improving the packaging and consequently gains in the resistances. The retention of water in this mix was within the expected, also favoring its application. Although the mix did not reach the value of the reference mortar in the tests, the difference did not make it impossible to apply ceramic blocks.

Finally, it can be stated that there is technical feasibility of the use of crusher residues in mortars and the substitution content of $10 \%$ of cement was the most adequate among the percentages tested, being this the mix that presented 
characteristics close to the reference in relation the other substitutions.

\section{Acknowledgment}

The authors are grateful to the Community University of Chapecó Region - UNOCHAPECÓ - for the financial support and availability of the infrastructure during the research and to UNIEDU (Santa Catarina University Scholarship Program) for financial support.

\section{References}

1. Maury MB, Blumenschein RN. Produção de cimento: Impactos à saúde e ao meio ambiente. Sustentabilidade em Debate. 2012;3(1):75-96.

2. Saraya MESI. Study physico-chemical properties of blended cements containing fixed amount of silica fume, blast furnace slag, basalt and limestone, a comparative study. Construction and Building Materials. 2014;72:104-112.

3. Salas DA, Ramirez AD, Rodríguez CR, Petroche DM, Boero AJ, Duque-Rivera J. Environmental impacts, life cycle assessment and potential improvement measures for cement production: a literature review. Journal of Cleaner Production. 2016;113:114-122.

4. Yilmaz M, Bakış A. Sustainability in Construction Sector. Procedia - Social and Behavioral Sciences. 2015;195:2253-2262.

5. Bordy A, Younsi A, Aggoun S, Fiorio B. Cement substitution by a recycled cement paste fine: Role of the residual anhydrous clinker. Construction and Building Materials. 2017;132:1-8.

6. Galvez-Martos JL, Schoenberger H. An analysis of the use of life cycle assessment for waste co-incineration in cement kilns. Resources, Conservation and Recycling. 2014;86:118-131.

7. Shen W, Liu Y, Yan B, Wang J, He P, Zhou C, et al. Cement industry of China: Driving force, environment impact and sustainable development. Renewable and Sustainable Energy Reviews. 2017;75:618-628.

8. Pliya P, Cree D. Limestone derived eggshell powder as a replacement in Portland cement mortar. Construction and Building Materials. 2015;95:1-9.

9. Thomas J, Harilal B. Properties of cold bonded quarry dust coarse aggregates and its use in concrete. Cement \& Concrete Composites. 2015;62:67-75.

10. Galetakis M, Soultana A. A review on the utilisation of quarry and ornamental stone industry fine by-products in the construction sector. Construction and Building Materials. 2016;102(Pt 1):769-781.

11. França BR, Azevedo ARG, Monteiro SN, Garcia Filho FC, Marvila MT, Alexandre J, et al. Durability of Soil-Cement Blocks with the Incorporation of Limestone Residues from the Processing of Marble. Materials Research. 2018;21(Suppl 1):e20171118.

12. Azevedo ARG, Alexandre J, Xavier GC, Monteiro SN, Vieira CMF. Characterization of Waste from Ornamental Stones for Use in Mortar. In: Carpenter JS, Bai C, Hwang JY, Ikhmayies S, Li B, Monteiro SN, et al., eds. Characterization of Minerals,
Metals and Materials 2014. Hoboken: John Wiley \& Sons; 2014. p. 379-386.

13. Vardhan K, Goyal S, Siddique R, Singh M. Mechanical properties and microstructural analysis of cement mortar incorporating marble powder as partial replacement of cement. Construction and Building Materials. 2015;96:615-621.

14. Oliveira KA, Nazário BI, de Oliveira APN, Hotza D, RauppPereira F. Industrial Wastes as Alternative Mineral Addition in Portland Cement and as Aggregate in Coating Mortars. Materials Research. 2017;20(Suppl 2):358-364.

15. Gemelli E, Cruz AAF, Camargo NHA. A Study of the Application of Residue from Burned Biomass in Mortars. Materials Research. 2004;7(4):545-556.

16. Pilar R, Schankoski RA, Dal Moro AJ, Repette WL. Avaliação de pastas de cimento Portland contendo cinza pesada moída. Matéria (Rio de Janeiro). 2016;21(1):92-104.

17. Silva RB, Fontes CMA, Lima PRL, Gomes OFM, Lima LGLM, Moura RCA, et al. Cinzas de biomassa geradas na agroindústria do cacau: caracterização e uso em substituição ao cimento. Ambiente Construído. 2015;15(4):321-334.

18. Fontes CMA, Toledo Filho RD, Barbosa MC. Sewage sludge ash (SSA) in high performance concrete: characterization and application. RIEM - IBRACON Structures and Materials Journal. 2016;9(6):989-1006.

19. Uygunoğlu T, Topçu IB, Çelik AG. Use of waste marble and recycled aggregates in self-compacting concrete for environmental sustainability. Journal of Cleaner Production. 2014;84:691-700.

20. Koppe A, Guindani EM, Mancio M. Avaliação do potencial de resíduo de Rochas Basálticas como matéria-prima para a produção de cimentos alternativos: processo de álcali- ativação. Revista de Arquitetura IMED. 2015;4(2):24-32.

21. Mendes TM, Guerra L, Morales G. Basalt waste added to Portland cement. Acta Scientiarum. 2016;38(4):431-436.

22. Uysal M, Sumer M. Performance of self-compacting concrete containing different mineral admixtures. Construction and Building Materials. 2011;25(11):4112-4120.

23. Ribeiro KFA, Branco MPV, Valin Junior MO, de Almeida ES. Estudo da substituição da areia pelo pó de pedra como agregado miúdo em argamassa. In: Anais do $4^{\circ}$ Encontro em Engenharia de Edificação e Ambiental; 2016 Nov 23-24; Cuiabá, MT, Brazil.

24. Brazilian Association of Technical Standards - ABNT (Associação Brasileira de Normas Técnicas). NBR NM 52 - Fine aggregate Determination of the bulk specific gravity and apparent specific gravity. Rio de Janeiro: ABNT; 2009.

25. Brazilian Association of Technical Standards - ABNT (Associação Brasileira de Normas Técnicas). NBR 13276-Mortars applied on walls and ceilings - Determination of the consistence index. Rio de Janeiro: ABNT; 2016.

26. Brazilian Association of Technical Standards - ABNT (Associação Brasileira de Normas Técnicas). NBR 7215 - Portland cement - Determination of compressive strength. Rio de Janeiro: ABNT; 1997.

27. Brazilian Association of Technical Standards - ABNT (Associação Brasileira de Normas Técnicas). NBR 13279-Mortars applied on walls and ceilings - Determination of the flexural and the 
compressive strength in the hardened stage. Rio de Janeiro: ABNT; 2005.

28. Brazilian Association of Technical Standards - ABNT (Associação Brasileira de Normas Técnicas). NBR 13277 - Mortars applied on walls and ceilings - Determination of the water retentivity. Rio de Janeiro: ABNT; 2005.

29. Brazilian Association of Technical Standards - ABNT (Associação Brasileira de Normas Técnicas). NBR 7222 - Concrete and mortar - Determination of the tension strength by diametrical compression of cylindrical test specimens. Rio de Janeiro: ABNT; 2011.

30. Brazilian Association of Technical Standards - ABNT (Associação Brasileira de Normas Técnicas). NBR 5751 - Pozzolanic Materials - Determination of pozzolanic activity with lime at seven days. Rio de Janeiro: ABNT; 2015.

31. Brazilian Association of Technical Standards - ABNT (Associação Brasileira de Normas Técnicas). NBR 12653 - Pozzolanic materials - Requirements. Rio de Janeiro: ABNT; 2015.

32. Nelson EB, Guillot D, eds. Well Cementing. Sugar Land: Schlumberger; 2006.

33. Brazilian Association of Technical Standards - ABNT (Associação Brasileira de Normas Técnicas). NBR 16697 - Portland cement - Requirements. Rio de Janeiro: ABNT; 2018.

34. Menezes RR, de Almeida RR, Santana LNL, Ferreira HS, Neves GA, Ferreira HC. Use of Kaolin Processing Waste for the Production of Ceramic Brick and Roof Tiles. Matéria (Rio de Janeiro). 2007;12(1):226-236.

35. Gartner E, Sui T. Alternative cement clinkers. Cement and Concrete Research. 2018;114:27-39.

36. Tenório JAS, Araújo FGS, Pereira SSR, Ferreira AV, Espinosa DCR, Barros A. Decomposição da fase majoritária do cimento Portland - Parte I: Alita Pura. REM: Revista Escola de Minas. 2003;56(2):87-90.

37. Ludwig HM, Zhang W. Research review of cement clinker chemistry. Cement and Concrete Research. 2015;78(PtA):24-37.

38. Mehta PK, Monteiro PJM, eds. Concreto: Microestrutura, propriedades e materiais. São Paulo: Ibracon; 2008.

39. Poulsen SL, Kocaba V, Le Saoût G, Jakobsen HJ, Scrivener KL, Skibsted J. Improved quantification of alite and belite in anhydrous Portland cements by ${ }^{29} \mathrm{Si}$ MAS NMR: Effects of paramagnetic ions. Solid State Nuclear Magnetic Resonance. 2009;36(1):32-44.

40. Choudhary HK, Anupama AV, Kumar R, Panzi ME, Matteppanavar $\mathrm{S}$, Sherikar BN, et al. Observation of phase transformations in cement during hydration. Construction and Building Materials. 2015;101(Pt 1):122-129.

41. Zampieri VA. Cimento Portland aditivado com pozolanas de argilas calcinadas: Fabricação, hidratação e desempenho mecânico. [Thesis]. São Paulo: University of São Paulo; 1993.

42. Lira HL, Neves GA. Feldspatos: conceitos, estrutura cristalina, propriedades físicas, origem e ocorrências, aplicações, reservas e produção. Revista Eletrônica de Materiais e Processos. 2013;8(3):110-117.

43. Alves RFP, Gadioli MCB. Caracterização das partículas totais em suspensão da produção de rochas ornamentais. In: Anais da $23^{\circ}$ Jornada de Iniciação Científica; 2015; Rio de Janeiro, RJ, Brazil.

44. Popp JH. Geologia Geral. São Paulo: LTC; 2002.

45. Bernal SA, Provis JL, Walkley B, San Nicolas R, Gehman JD, Brice DG, et al. Gel nanostructure in alkali-activated binders based on slag and fly ash, and effects of accelerated carbonation. Cement and Concrete Research. 2013;53:127-144.

46. Silva PHS, Dias FAC, Vieira BLM, Salles PHL, Nascimento JC, Toledo TA, et al. Estudo da decomposição térmica de calcita. In: Anais do $56^{\circ}$ Congresso Brasileiro de Química; $2016 \mathrm{Nov}$ 7-11; Belém, PA, Brazil.

47. Breitenbach SB, Santos OC, Andrade JCS, Nascimento RM, Martinelli AE. Adição de resíduo do polimento de porcelanato em argamassas de restauro à base de cal. Cerâmica. 2017;63(367):395-401.

48. Araújo GS. Estudo de parâmetros texturais das areias para argamassas de revestimento através da análise de imagens. [Dissertation]. Vitória: Federal University of Espírito Santo; 2001.

49. Canova JA. Substituição do cimento por finos de britagem em argamassa de revestimento. Ciência \& Engenharia. 2017;26(2):11-19.

50. De Larrard F. Concrete Mixture Proportioning: A Scientific Approach. London: E \& FN Spon; 1999. 